\title{
Exploitation of Biogas Resources for Electric Vehicle Charging Station in Bangladesh
}

\author{
Ashish Kumar Karmaker* ${ }^{1}$, Md. Mijanur Rahman ${ }^{1}$, Md. Alamgir Hossain ${ }^{1,2}$, Md. Raju Ahmed ${ }^{1}$ \\ ${ }^{*}$ Department of Electrical and Electronic Engineering, Faculty of Electrical and Electronic Engineering, Dhaka \\ University of Engineering \& Technology, Gazipur, 1707
}

${ }^{2}$ School of Engineering and Information Technology, University of New South Wales-Canberra, Canberra, Australia

*Correspondence: $\underline{\text { ashish@duet.ac.bd }}$

\begin{abstract}
The abrupt increase of the electric vehicles in Bangladesh needs huge amount of power. As a result, alternative energy sources are emphasized due to limited fossil fuels in order to develop a sustainable energy sector with environment friendly resources. Bangladesh has an enormous potential in the field of renewable resources like biogas and biomass. This paper presents $20 \mathrm{~kW}$ electric vehicle charging station (EVCS) utilizing biogas resources where maximum energy requirement is $100 \mathrm{kWh}$. In this paper, the biogas based EVCS is designed using MATLAB Simulink and HOMER software. Daily 15-20 electric vehicles can be recharged their batteries using the proposed charging station. The proposed system offers lower cost of energy compared to the grid electricity. Moreover, the proposed charging station shows $68.75 \%$ reduction in $\mathrm{CO}_{2}$ emission than grid based charging station. In addition, the proposed EVCS will save monthly \$ 16.25 and \$27.50 respectively for easy bike and auto rickshaw type electric vehicles in Bangladesh.
\end{abstract}

Keywords: Electric vehicle charging station (EVCS), HOMER, MATLAB, $\mathrm{CO}_{2}$ emission, payback period

\section{Introduction}

Bangladesh is an energy-starved country where natural gas and petroleum products are the main sources of energy [1]. Transportation sector consumes $46.46 \%$ of the total petroleum consumption and $6 \%$ of the total natural gas consumption. In addition, only $8 \%$ of the total demand of petroleum is reserved in Bangladesh and every year about 1.2 million tons of crude oil and 2.6 million tons of refined petroleum products need to import [2,3]. So, the government has to pay a high amount of budget to import it from abroad. Besides this scenario, greenhouse gas (GHG) emissions due to the transport sector increases significantly [4]. Growing concern about the GHG emissions to the environment encourage to use electric vehicles $(\mathrm{EV})$ that is the cheapest mode of transportation. In Bangladesh due to rapid industrialization and increasing income level, peoples are using electric vehicles that have the several key benefits including reduction of sound pollution, fumes and GHG emission. However, the steady increase in the number of EVs in Bangladesh needs 500 MW power daily from the national grid. This huge demand creates a burden on the grid and affects the stability \& power quality of the grid [5]. Moreover, almost all of the EVs are charged their batteries from the residential connection which is illegal. The EV owner pays the bill as residential consumer that leads the failure of the power sector to reach the profitability margin. Bangladesh has an enormous potential for renewable energy resources like solar, biogas/biomass, wind, hydro etc. [6]. These renewable resources can be used to charge the EVs that can help to reduce pollution [7]. Different institutions are working jointly with the Government of Bangladesh to utilize renewable resources. Although, solar charging stations are establishing in different cities of Bangladesh.
These are not sufficient and therefore a lot of charging stations is required to work with the EV charging by renewables.

In addition, solar-based charging station can only work when solar energy is available. In this case, biogas resources can increase the effective operational hours for charging EVs [8]. To the best of the authors knowledge, no initiative up to date has been taken place to determine the feasibility of biogas/biomass incorporation in EV charging stations in Bangladesh. Therefore, this study carried out to open a new door for connecting biogas in EV charging. The main contributions of this paper are given as follows:

a) To analyse the potential of biogas/biomass resources available in Bangladesh;

b) To design the proposed EVCS by MATLAB Simulink;

c) To analyse the cost and environmental benefits of the proposed EVCS by HOMER software and

d) To illustrate the social benefits of the proposed EVCS.

In this paper, the prospects and potentials of biogas/biomass resources are analysed. Based on the potentiality of biogas resources, a novel model for EV charging scheme in Bangladesh is proposed in this research. Mathematical modelling and analysis are performed with the help of MATLAB Simulink. Environmental impacts and benefits are also demonstrated in this research using HOMER software. Social benefits of the EV adaptation involving biogas energy are illustrated in the paper.

\subsection{Literature Review}

Growing popularity of EVs in Bangladesh, encourage researcher to do research with the establishment of EVCS and utilize the renewable energy like biogas and biomass. 
The literature survey is divided into three parts. These include the assessment of the biogas/ biomass potential in Bangladesh, existence of the charging stations by renewable energy and the charging stations using biogas/biomass. The electricity and transportation sector requires a major portion of the total fossil fuel demand in Bangladesh. However, the fossil fuels are limited in stock and have to pay large budget to import it from abroad. Thus it is high time to use renewable energy resources instead of petroleum resources for sustainable development in

Bangladesh [9]. Renewable energy resources are very much eco-friendly and emit less amount of GHGs [10]. To promote development in urban areas as well as rural areas it is necessary to fulfil the electricity demand. In rural areas where grid electricity is unavailable, electricity demand can meet using renewable resources like solar, biogas, wind etc. Solar energy is available in all over the country to generate electricity effectively for 5-6 hours with solar irradiation of 4 to $6.5 \mathrm{kWh} / \mathrm{m}^{2}$-day [11]. Necessary wind speed in Bangladesh is limited to only coastal and off-shore areas [12]. Moreover, the biogas resources are available throughout the country. Thus, the proper use of biogas/biomass resources for electricity generation increase the effective operation hours. Bangladesh has an abundant resource of biogas/biomass for power generation. M. S. Shah et al. estimated the 7.6775 billion $\mathrm{m}^{3}$ biogas potential in the fiscal year of 2012-13 which can be used as bio-CNG of 5.088 billion $\mathrm{m}^{3}$ [13]. As an agricultural country, biomass energy has a great potential to strengthen the industrial and manufacturing sectors in Bangladesh [14]. In a study, the biomass potential is explored in Bangladesh through gasification technology and concludes that agriculture residue, rice husk, bagasse, wheat straw, jute stalks, maize residues, coconut shells, forest residue and municipal solid waste (MSW) are the main biomass resources [15]. According to waste statistics from Sustainable and Renewable Energy Development Authority (SREDA) and Waste Concern, Bangladesh, it is found that cow dung, poultry waste, MSW can be a potential source of electricity generation in Bangladesh [16, 17]. With increasing population, the volume of solid waste is increasing enormously which may become a good source of energy as well as a part of solid waste management. Controlling temperature and $\mathrm{P}^{\mathrm{H}}$ of the waste are the main factors of biogas production [18]. Potentiality of biogas resource facilitates the sustainable development which is analysed in a legal framework and future market situations [19]. A study shows that, approximately 4 million biogas plants can be established in Bangladesh which can meet the $20 \%$ of the total household demand [20].

A small-scale biogas plant of $3.2 \mathrm{~m}^{3}$ in Bangladesh is capable of mitigating GHG emission compared to the conventional power station. In addition, the environmental impacts are determined by evaluating biogas, methane, construction materials and feedstock demand [21]. In South Africa, a biogas plant was found economically viable which generates $166.6 \mathrm{~kW}$ power and $277.7 \mathrm{~kW}$ heat from cattle manures of $58330 \mathrm{~kg} /$ day [22]. Co-digestion may increase the biogas production efficiency and efficient use of biogas resources [23]. Anaerobic co-digestion of cow dung with kitchen waste, rice husk, water hyacinth is analyzed to get the maximum possible benefits of biogas resources and found the efficiency of biogas production increases up to
$150 \%$ [24]. Biogas can be used as bio-CNG (bio-methane), combined heat and power generation. Only $35 \%$ of biogas is converted into electricity, $50 \%$ is converted into heat and $15 \%$ is into losses [25]. Transport vehicle (CNG driven) can be run by using bio-CNG whereas electric vehicle from electricity generation from bioenergy. The heat produced from biogas plant can be used for heating applications like the gas stove for cooking. Bi-product of biogas plant can be used as fertilizer/fish feed which consists of nitrogen, phosphorous, carbon etc. [26, 27]. Different studies and research are carried out in the context of Bangladesh to design, development and performance analysis of biogas plants using the locally available waste material in a costeffective manner [28-34]. Various factors such as biogas potential of feedstock, design of digester, inoculum, nature of substrate, $\mathrm{pH}$, temperature, loading rate, hydraulic retention time (HRT), C: $\mathrm{N}$ ratio, volatile fatty acids (VFA), etc. influence the biogas production $[35,36]$.

Bangladesh is suitable for establishing biogas plant due to its climate. The ideal temperature for anaerobic digestion is $35^{\circ} \mathrm{C}$ where the temperature of Bangladesh varies from $6{ }^{\circ} \mathrm{C}$ to $35^{\circ} \mathrm{C}$. The inner temperature of a biogas digester varies from $22^{\circ} \mathrm{C}$ to $30^{\circ} \mathrm{C}$ that is very close to the optimum requirement [37]. Renewable energy resource based electricity generation helps to meet up present energy crisis to charge the EVs. EVs charged by renewable based charging station offers less GHG emission than grid- based charging station [38]. The electric vehicle can be used as a load or distributed energy source in bidirectional power flow method popularly known as vehicle to grid technology. V2G offers reactive power compensation, active power regulation, load balancing which are capable of increasing efficiency and grid reliability [39]. In a research, the real time simulation for vehicle to grid, grid to vehicle and vehicle to vehicle technology are implemented and described charging \& discharging requirements. Also the energy management system is needed for dynamic price model of multiple EV charging station [40]. Feasibility analysis of solar-based electric vehicle charging station and their design consideration is assessed in different research where the method was found economically and environmentally acceptable [41, 42]. Design of EVCS using solar and biogas resources can make the system cost-effective and reduces the environment pollution significantly [43]. However in case of solar, the effective hours are very low. As EVs need the power to charge at any time of the day, it is important to use biogas resources for EV charging to increase the effective hour and management of wastes in a proper way [44]. Single EV can draw less amount of power where the aggregate effect of EVs can be a threat to the normal electric power system infrastructure and its operation. Also the charging load profile can be designed using the time of use to recharge the battery [45].

A study in the context of Denmark shows that biogas used for EV charging reduces the fuel consumption and GHG emission [46]. Biogas can be converted into bio-CNG which is further used for transportation vehicles. Biogas applications for EV charging are seen in different areas of the world with the emphasis on renewable energy and reduce the use of fossil fuel \& GHG emission from transport sector [47-52]. Fuzzy logic based feed stock selection for biogas production according to $\mathrm{C} / \mathrm{N}$ ratio of the waste was 
performed in a research [53]. A MIMO fuzzy logic based system was developed for prediction of biogas and methane production rates in a pilot - scale mesospheric USAB reactor treating molasses waste water [54]. Although the huge potentiality of biogas/biomass in Bangladesh, there is very few research performed to use it in the transportation vehicle i.e. Electric Vehicle charging. The eco-friendly, cheapest and effective waste management facilities grow up our interest to perform this research on the use of biogas resources.

\subsection{Electric vehicle in Bangladesh}

Electric vehicles are now running almost all corners of the Bangladesh. There are three types of electric vehicles used in Bangladesh- such as- Easy bike carries 5 passengers. Auto-rickshaw carries 2 passengers and Electric motorcycle carries 2 passengers. These EV can travel for distances ranges from $70-120 \mathrm{~km}$ and energy requires per day is about 8-11 kWh. All of these vehicles are charged from the utility grid as a residential consumer. However, the EV charging rate declared by government is higher than residential consumer and EV owner treated as a business consumer. Thus, the government is facing difficulties with earning profit from power sector. It is well known that, unavailability of the charging stations and load shedding affects the EV charging. Although, the government has taken initiatives by establishing solar charging station (SCS) in different points of Bangladesh. The government needs a massive plan to establish new charging stations in all over the country and reduction of the pressure on the grid performance. An EV charged from the grid-based charging station requires 120-150 BDT. per day for full charging. For a km run, it needs approximately $0.11 \mathrm{kWh}$ and costs BDT. 1.078. Specifications of the EVs used in Bangladesh are given in Table [1].

Table [1]: specifications of Electric Vehicles in Bangladesh

\begin{tabular}{|c|c|}
\hline $\begin{array}{c}\text { Easy Bike and Auto- } \\
\text { rickshaw }\end{array}$ & Electric motor cycle \\
\hline Power: 500 W-1000 W & $\begin{array}{c}\text { Power: 1200 W-2500 } \\
\mathrm{W}\end{array}$ \\
\hline Voltage: 36/48/60 V & Voltage: 60/72 V \\
\hline Battery: 20 Ah-30 Ah & $\begin{array}{c}\text { Battery: 20 Ah lead } \\
\text { acid gel battery }\end{array}$ \\
\hline Charging time: 6-7 hours & $\begin{array}{c}\text { Charging time: 6-8 } \\
\text { hours }\end{array}$ \\
\hline $\begin{array}{c}\text { Max. speed: } 30-40 \mathrm{~km} / \mathrm{h} \\
\text { Max. speed: } 50-80 \\
\text { km/h }\end{array}$ \\
\hline $\begin{array}{c}\text { Driving distance: } 70-100 \\
\mathrm{~km}\end{array}$ & $\begin{array}{c}\text { Driving distance: } 60- \\
80 \mathrm{~km}\end{array}$ \\
\hline
\end{tabular}

\subsection{Potentials of Biogas Resources in Bangladesh}

Biogas is a source of energy which can be used for the purpose of electricity generation, cooking and other heating applications. Typically, it is a mixture of methane and carbondi-oxide, produced by the breakdown of the organic wastes without oxygen. Biomass is also a resource of bio-energy which consists of wood, crop residues, foods, garbage and landfill gas etc. In Bangladesh, huge potential of biodegradable resources like animal waste, food substrate, wood \& paper, garbage, municipal solid wastes are treated as the main sources of biogas. The chemical composition of biogas is shown on the Table [2]. The commonly used fuels with their calorific value and thermal efficiency are shown in Table [3].

Table [2]: Chemical composition of Biogas [52]

\begin{tabular}{|c|c|}
\hline Chemical parameter & \% Content \\
\hline $\mathrm{CH}_{4}$ & $50 \%-75 \%$ \\
\hline $\mathrm{CO}_{2}$ & $25 \%-50 \%$ \\
\hline $\mathrm{N}_{2}$ & $0-10 \%$ \\
\hline $\mathrm{H}_{2}$ & $0-1 \%$ \\
\hline $\mathrm{H}_{2} \mathrm{~S}$ & $0-3 \%$ \\
\hline $\mathrm{O}_{2}$ & $0-0.5 \%$ \\
\hline
\end{tabular}

Table [3]: commonly used fuels in Bangladesh [53]

\begin{tabular}{|c|c|c|}
\hline $\begin{array}{c}\text { Commonly used } \\
\text { fuels }\end{array}$ & $\begin{array}{c}\text { Calorific Values } \\
\text { in kCal }\end{array}$ & $\begin{array}{c}\text { Thermal } \\
\text { efficiency }\end{array}$ \\
\hline Biogas & $4713 / \mathrm{m}^{3}$ & $60 \%$ \\
\hline Dung Cake & $2093 / \mathrm{kg}$ & $11 \%$ \\
\hline Firewood & $4978 / \mathrm{kg}$ & $17.3 \%$ \\
\hline Diesel (HSD) & $10550 / \mathrm{kg}$ & $66 \%$ \\
\hline Kerosene & $10850 / \mathrm{kg}$ & $50 \%$ \\
\hline Petrol & $11000 / \mathrm{kg}$ & - \\
\hline
\end{tabular}

2.1 Animal waste: Animal wastes can be used as potential biomass resource. In Bangladesh, there are 150,000 poultry farms of chicken and duck. According to the statistics obtained for the fiscal year 2016-17, waste generation per day from different livestock (i.e. Cattle, buffalo, chicken and duck etc.) is shown in Table [4]. The wastes produced from these livestock can be utilized to generate power.

Table [4]: Waste generation from livestock [54]

\begin{tabular}{|c|c|c|}
\hline Waste type & $\begin{array}{c}\text { No. of livestock } \\
\text { (millions) }\end{array}$ & $\begin{array}{c}\text { Waste generation } \\
\text { (tons/day) }\end{array}$ \\
\hline Cattle dung & 23.93 & $1,79,475$ \\
\hline Buffalo dung & 1.47 & 14,700 \\
\hline Chicken waste & 275.18 & 27,518 \\
\hline Duck waste & 54.01 & 5,401 \\
\hline
\end{tabular}

2.2 Agriculture residues: Agriculture residues contribute largely in biomass generation. These residues are mainly rice husk, crops, sugarcane bagasse, forest residues, jute and vegetables. Bangladesh is a major rice producing country. Rice straw and rice husk are the main residues of rice. Depending on the residue collection period, the crop residues can be categorized as- field residues and processed residues. The rice straw and rice husk residue recoverable rate is $35 \%$ and $100 \%$ respectively. Sugarcane residue is one of the 
powerful resource of biomass. In Bangladesh, the volume of sugarcane cultivation reached about 4,434,070 metric tons. The tops $\&$ leaves, bagasse residues are utilized as biomass energy where residue recoverable rate for processed bagasse is $73.42 \%$. Jute is another biomass source in which the recoverable rate is $37.12 \%$. All of these agriculture residues can be a good source of biomass for power generation and also effective in heating applications [58].

2.3 Municipal solid waste (MSW): Waste disposal is an emerging problem in almost all of the urban areas. Rapid urbanization and industrialization increase the rate of waste disposal per day. The per capita MSW generation rate in Bangladesh is approximately $0.5 \mathrm{~kg}$. The MSW generation scenario in urban areas of Bangladesh is shown in Table [5] below.

Table [5]: MSW generation scenario in urban areas of Bangladesh [16]

\begin{tabular}{|c|c|c|c|}
\hline Year & $\begin{array}{c}\text { Total } \\
\text { population }\end{array}$ & $\begin{array}{c}\text { Waste } \\
\text { generation } \\
\text { rate }\end{array}$ & $\begin{array}{c}\text { Waste } \\
\text { generation } \\
\text { (tons/day) }\end{array}$ \\
\hline 1991 & $20,872,204$ & 0.49 & $9,873.5$ \\
\hline 2001 & $28,808,477$ & 0.5 & 11,695 \\
\hline 2004 & $32,765,152$ & 0.5 & 16,382 \\
\hline 2015 & $54,983,919$ & 0.5 & 27,492 \\
\hline 2025 & $78,440,000$ & 0.6 & $\begin{array}{c}47,064 \\
\text { (Projected) }\end{array}$ \\
\hline
\end{tabular}

Near about 4200 tons of MSW generates in Dhaka city in every day. The improper management of MSW creates a negative environmental impact and it appears to be a growing concern now a days. The proper management of these wastes can be a tremendous source of energy generation. The government and other stakeholders are thinking about this matter. Recently GIZ, German development agency has performed a detailed feasibility study with the collaboration with Sustainable and Renewable Energy Development Authority (SREDA), Bangladesh to identify the prospects and potentials of MSW to electricity generation in Keraniganj, Dhaka. The experts recommended dry fermentation technology for the waste to energy project (WTE), Keraniganj. Depending on the suitable waste management, the expert advices to establish 4-5 MW power plant based on organic waste and industrial waste. Bangladesh Power Development Board (BPDB) has assigned to establish $1 \mathrm{MW}$ combined heat and power unit by the government.

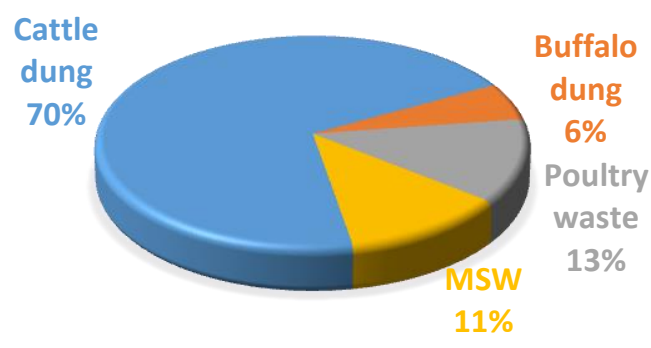

Fig. 1: Waste generation per day in Bangladesh.
Waste generation according to the type of wastes is shown in Figure 1. In Bangladesh, Infrastructure Development Corporation Limited (IDCOL) and Grameen Shakti are working to develop maximum number of biogas plant and they have established approximately 80000 small biogas plant. Government of Bangladesh takes initiatives to established 1 MW biomass based plant and 5 MW of biogas based plant in different regions [59].

\subsection{System Components selection and design}

To develop the EV charging station based on biogas resources requires energy demand, biogas/biomass potential, size of the biogas plant, available space for plant, initial cost, O\& $M$ cost per year and finally the daily output from the plant. The design and development phases of the proposed EVCS are given below.

3.1 Energy required for EVs: In this research, $20 \mathrm{EVs}$ are considered for charging by biogas resources daily. It is assumed that, the proposed charging station can continue the operation for 24 hours daily. EV comes at charging station to charge their batteries according to the SOC. The load curve is shown in Figure 2 which describes the variation of EV load with time. Figure 2 shows that at the evening period load gradually increases and at morning hour load is relatively lower than other time.

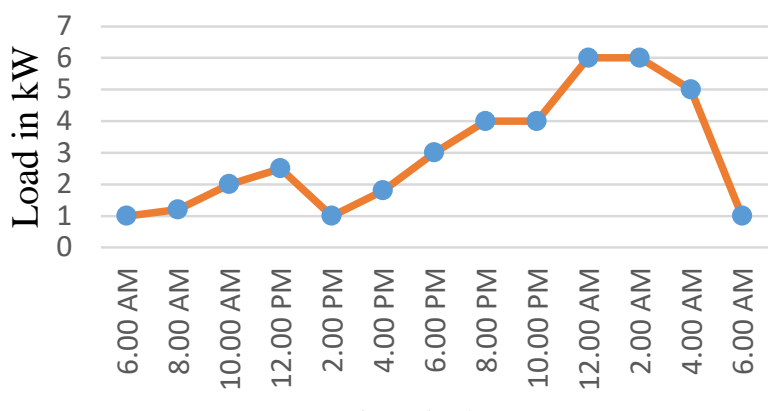

Time in hour

Fig. 2: Daily load curve of the proposed EVCS

Fig. 2 shows that at the evening period load gradually increases and at morning hour load is relatively lower than other time.

3.2 Waste required for the power generation: Total waste requires for the electricity generation for the EV charging is the important parameter for designing biogas based charging station. In this research, a charging station is designed where the maximum energy requirement is approximately 100 $\mathrm{kWh}$ and load curve is plotted in Fig.2. Use of poultry waste, cow dung and MSW are considered for power generation. However, the energy output will not be same for different types of wastes. Therefore, calculation of electricity from different wastes are need to evaluate first.

Possible amount of electricity generation,

$$
P_{E}=\frac{W * B_{w}}{B_{k w}} ;
$$

where $W, B_{W}$ and $B_{k W}$ stands for total waste in $\mathrm{kg}$, biogas production per $\mathrm{kg}$ of waste and biogas required for $1 \mathrm{~kW}$ electricity generation, respectively. It is assumed that for 
poultry waste \& MSW biogas production per $\mathrm{kg}$ of waste is $0.074 \mathrm{~m}^{3}$ and for cow dung biogas produced per $\mathrm{kg}$ is 0.034 $\mathrm{m}^{3}$. It is also assumed that biogas required for $1 \mathrm{~kW}$ electricity generation is $0.71 \mathrm{~m}^{3}$. Table [6] shows that, different waste requirement for biogas production.

Table [6]: Waste requirement and corresponding biogas generation

\begin{tabular}{|c|c|c|c|}
\hline $\begin{array}{c}\text { Waste } \\
\text { type }\end{array}$ & $\begin{array}{c}\text { Waste } \\
\text { /day (kg) }\end{array}$ & $\begin{array}{c}\text { waste } \\
\text { required(kg) }\end{array}$ & $\begin{array}{c}\text { Biogas } \\
\text { produced/day }\left(\mathbf{m}^{\mathbf{3}}\right)\end{array}$ \\
\hline $\begin{array}{c}\text { Cow } \\
\text { dung }\end{array}$ & 360 & 51 & 12.24 \\
\hline $\begin{array}{c}\text { Poultry } \\
\text { waste }\end{array}$ & 150 & 1500 & 11.10 \\
\hline MSW & 260 & 520 & 18.50 \\
\hline
\end{tabular}

It is worth mentioning that outputs of a biogas plant are in the forms of heat and biogas. Only $35 \%$ of the biogas is used for generating electricity but $65 \%$ of output energy is utilized for mechanical losses and heat. The heat produced from this plant can be a good source for cooking. Fig.3 shows the monthly collection of biomass from the nearby cattle farm, poultry farm and urban areas of Bangladesh. Collected biomass is firstly processed and stored into a tank for further anaerobic digestion in the digester. According to the weight of the processed biomass, biogas generator generates electricity.

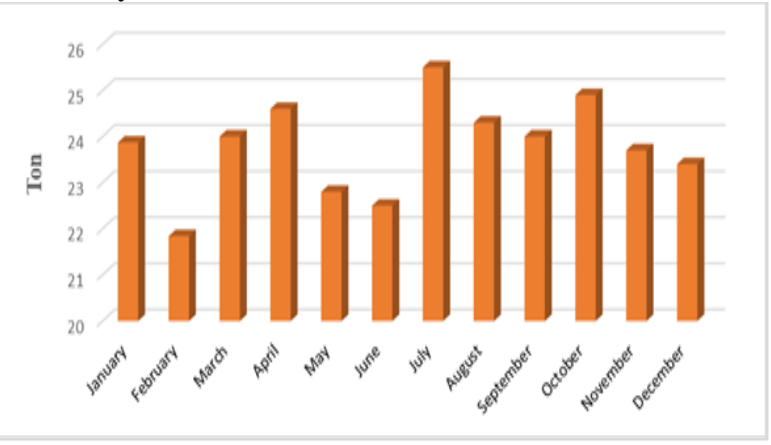

Fig.3: Monthly available biomass generation.

Fig.3 shows the monthly collection of biomass from the nearby cattle farm, poultry farm and urban areas of Bangladesh. Collected biomass is firstly processed and stored into a tank for further anaerobic digestion in the digester. According to the weight of the processed biomass, biogas generator generates electricity.

3.3 Digester design: Anaerobic digester is the main component of a biogas plant in which biogas is produced after breakdown of organic waste in the absence of oxygen. The produced biogas can be used for driving transport vehicle and generating electricity. The volume of the digester is the product of the daily substrate input and the retention time which is expressed as equation (2) [57]. $V_{D}=S_{i} * R_{T}$
Retention time depends upon the temperature. In this research, retention time is assumed as 40 days for the temperature of $30^{\circ} \mathrm{C}$. The substrate input is a combination of waste supplied to a digester and water. $S_{i}=$ waste $_{-} k g+$ water $_{-} k g$;

Volume of substrate input,

$$
V_{\text {substrate }}=\frac{S_{i}}{\rho} ;
$$

Where $\rho$ is the density of substrate input. Available size of biogas digester in Bangladesh and their cost \& substrate requirement is shown in Table [7] below.

Table [7]: Cost and size of the digester

\begin{tabular}{|c|c|c|c|}
\hline $\begin{array}{c}\text { Size of } \\
\text { digester } \\
\left(\mathbf{m}^{\mathbf{3}}\right)\end{array}$ & $\begin{array}{c}\text { Biomass } \\
\text { required } \\
(\mathbf{k g})\end{array}$ & $\begin{array}{c}\text { Cost of } \\
\text { digester } \\
\text { (USD) }\end{array}$ & $\begin{array}{c}\text { Operating } \\
\text { hours/day }\end{array}$ \\
\hline 3.2 & 50 & 538 & $7-8$ \\
\hline 4.8 & 130 & 650 & $10-12$ \\
\hline 2.0 & 30 & 350 & $4-5$ \\
\hline
\end{tabular}

As in this research, the size of the digester is found $40 \mathrm{~m}^{3}$ to produce $100 \mathrm{kWh}$ of electricity per day. Therefore, a special design of $40 \mathrm{~m}^{3}$ digester is required for this EVCS. Otherwise, $4.8 \mathrm{~m}^{3}$ digester of 8 nos. and a $3.2 \mathrm{~m}^{3}$ digester can fulfil the demand of $40 \mathrm{~m}^{3}$.

3.4 Gasholder: The gasholder is used in biogas plant to hold the biogas produced by the digester. The design considerations are rate of biogas generation and the rate of consumption. It should be designed such a way so that it can hold maximum amount of biogas during zero consumption period.

$V_{g}=1.15 * \max \left(V_{\text {consumption_rate }} * V_{\text {zero_consumption }}\right)$;

(5)

The ratio of digester and gasholder is typically 3:1 or 10: 1 .

3.5 Biogas generator: The power generated from the biogas generator depends on the torque and speed of the generator. The biogas is converted into rotating force or torque by an engine which is directly proportional to the power generated. Assuming the mechanical losses and copper losses, the output electrical power is obtained. This is approximately $35 \%$ of the total biogas energy.

$$
P_{\text {out_kW }}=(T * N) / 5252 ;
$$

For a 4-pole generator and frequency of $50 \mathrm{~Hz}$, speed, $\mathrm{N}=1500 \mathrm{rpm}$. A $4 \mathrm{~kW}$ generator can run with the output of $4.8 \mathrm{~m}^{3}$ digester at 8-10 hours effectively.

3.6 Rectifier: It is used to convert the AC voltage into DC for charging EVs. It is assumed that rectifier has $90 \%$ efficiency. The rectifier is connected to the charging assemblies where EV is charged.

$$
P_{D C}=\eta * P_{A C}
$$


3.7 Battery: The battery is used to store the excess energy when the EV is unavailable to charge. Therefore, it should be designed very carefully to handle the emergency situation. It is assumed that, the battery bank is designed to store the energy of $50 \mathrm{kWh}$. The battery capacity is expressed as

$$
W h=A h * \text { Voltage; }
$$

So for $30 \mathrm{kWh}$ energy and terminal voltage of $12 \mathrm{~V}$, there are a total number of batteries required $=25$ of $100 \mathrm{Ah}$.

The charging profile of an EV depends upon the following factors- i.e. EVs arrival time, charging level and time required to recharge the battery. The energy required to charge the battery can be determined by following equation [61].

$E^{K}=\frac{C^{K}}{\eta_{\text {charger }}^{K}} \times\left(1-S O C^{K}\right) ;$

Where $\mathrm{E}^{\mathrm{K}}$ is the total energy required to charge the battery $(\mathrm{kWh}), \mathrm{SOC}^{\mathrm{k}}$ is the percentage of remaining charge in the vehicle battery, $C^{k}$ is the battery capacity and $\eta_{\text {charger }}^{\mathrm{k}}$ is the efficiency of the vehicle battery charger assumed as $90 \%$.

\subsection{Design of the proposed EVCS}

Conceptual design of the biogas based EVCS is shown in Fig. 4. Animal wastes and other wastes are collected and processed to recover the energy content. Mixer is used to mix up the slurry which is made by a combination of processed waste and water. Then, anaerobic digestion occurs at a temperature of $35^{\circ} \mathrm{C}$ at digester and biogas is produced. The biogas is stored into a gasholder. In Bangladesh, fixed dome type digester is often used. The size of the digester is determined by the retention time and daily feedstock/substrate input. Gasholder stores the biogas produced by digester at low consumption period. The produced biogas is warm and it contains large amount of water vapour. When cooled, most of the water will condense out and it can be supplied back to make slurry. Gas purification plant mainly removes the $\mathrm{H}_{2} \mathrm{~S}$ content, because it is corrosive with the $\mathrm{CO}_{2}$ and water. Digestate slurry can be used to land and ponds as fertilizer and fish feed. Biogas generator unit consists of an engine and a generator. An engine converts the chemical energy into mechanical energy which is further used to run a generator to generate electricity.

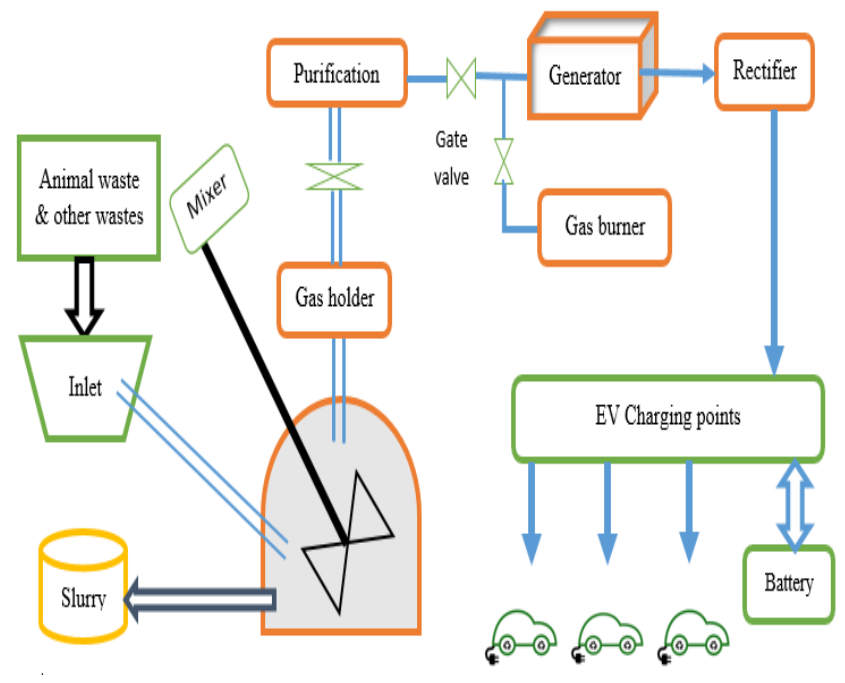

Fig. 4: Biogas based proposed EVCS. Biogas based EVCS designed using MATLAB Simulink is shown in Fig.5.

\subsection{Design of EVCS by using MATLAB Simulink:}

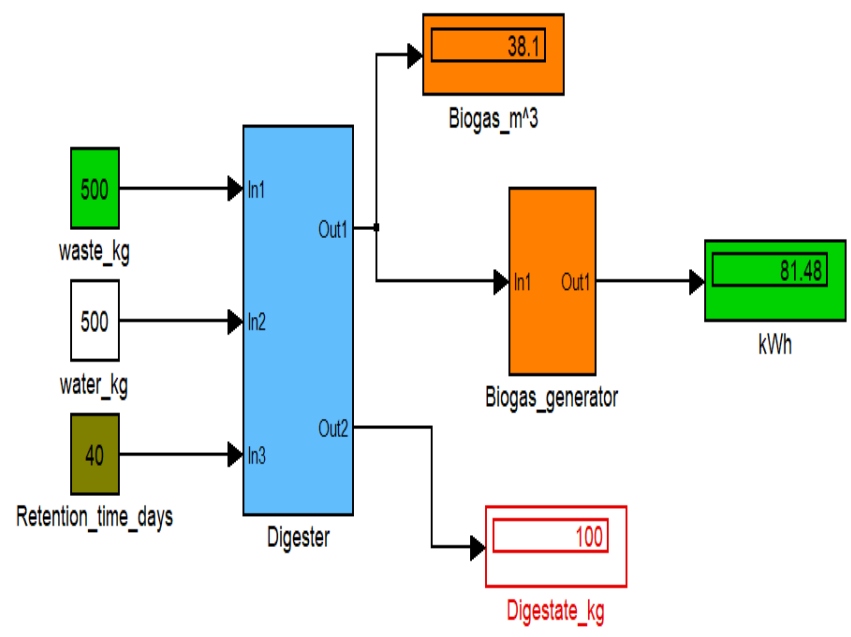

Fig.5: Proposed EVCS using MATLAB Simulink

The proposed EVCS is designed for generating electricity and further charging EVs according to the battery SOC. The monthly optimum power generation from the proposed EVCS is shown in Fig. 6 where the maximum generation is in the month of July and the minimum in February. It depends upon the biomass collection. The processed biomass is ready for anaerobic digestion in the fixed dome type or floating dome type digester. In accordance with the calorific value of the waste materials, the biogas produces and thus electricity is generated. In a biogas plant, the production of biogas is not only the output parameter but digestate produces from the anaerobic digestion is also carries importance. Digestate can be formed as a good fertilizer and selling this bi-product at a minimum rate to the farmers, developer can minimize the running cost of the plant. In the proposed EVCS, monthly digestate production from the biogas plant is plotted in Fig. 7. 


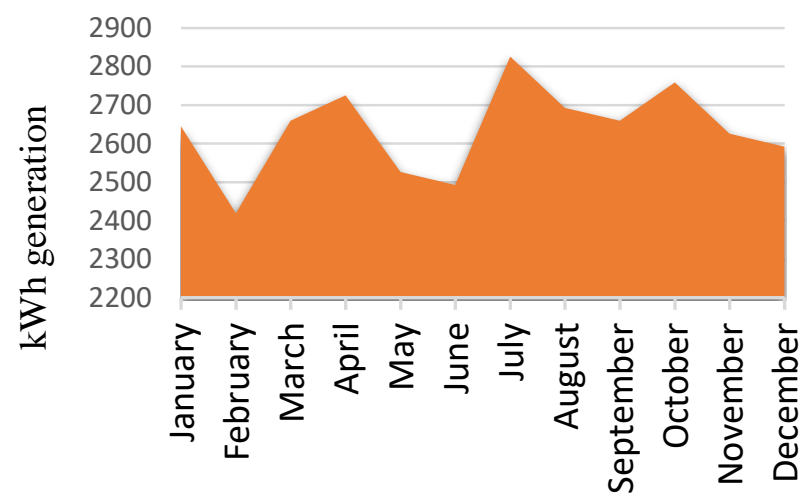

Fig. 6: Electricity generation scenario of the proposed EVCS

In a biogas plant, the production of biogas is not only the output parameter but digestate produces from the anaerobic digestion is also carries importance. Digestate can be formed as a good fertilizer and selling this bi-product at a minimum rate to the farmers, developer can minimize the running cost of the plant. In the proposed EVCS, monthly digestate production from the biogas plant is plotted in Fig. 7 .

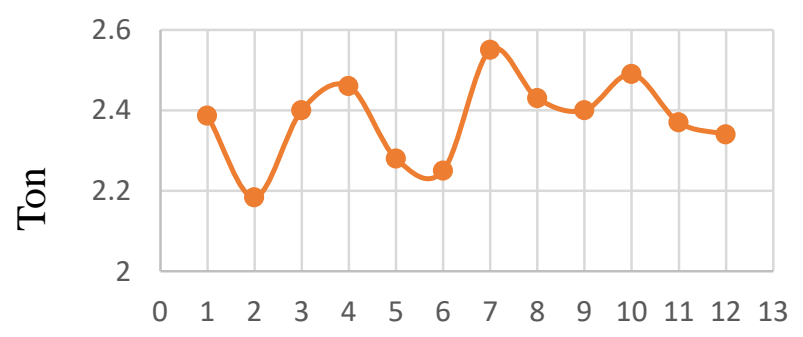

\section{Months from January to December}

Fig. 7: Month wise digestate production from the proposed EVCS.

\subsection{Cost Analysis:}

The economic parameters related to the proposed EVCS consist of initial capital cost, O\&M cost, replacement cost, cost of energy, payback period. These parameters play a vital role for accomplishment and desired success of the project. Table [8] shows the economic parameters of the proposed EVCS using biogas resources. The $\mathrm{O} \& \mathrm{M}$ cost can be minimized by selling slurry as fertilizer at a minimum rate. HOMER analysis helps to determine the COE, annual cash flow, payback period and profitability index.

Table [8]: Economic parameters

\begin{tabular}{|cc|}
\hline Item & Cost (BDT) \\
\hline Digester & $1,50,000$ \\
\hline Gasholder & 15,000 \\
\hline Purification unit & 20,000 \\
\hline Pipe line & 18,000 \\
\hline Biogas generator & $8,00,000$ \\
\hline Battery bank & $1,00,000$ \\
\hline Charging assemblies & 12,000 \\
\hline O \& M Cost & $5,50,000$ \\
\hline Total Cost/investment & $1,665,000$ \\
\hline Cost of Energy & 5.70 \\
\hline
\end{tabular}

5.1 Cost of energy: The EVCS delivers power to the consumer on the basis of power demand and power availability. The cost of charging EVs per $\mathrm{kWh}$ is called the cost of energy (COE). In case of the proposed EVCS, the charging cost can be determined by the following equation [62].

$$
C O E=C_{\text {Base }}+C_{\text {variable }}
$$

The $\mathrm{C}_{\text {Base }}$ is the base or minimum value of the EV charging cost and $\mathrm{C}_{\text {variable }}$ is the variable cost of charging depending of the time. It may vary according to the peak and off-peak periods and thus the charging cost also varies. In this proposed research, the COE per kWh for EV charging is found BDT.5.70.

5.2 Payback period: It is expressed in years after which the investment is equal to its total cash in-flow. It indicates the project will be profitable at the end of the payback period.

Payback Period, PBP $=\frac{\text { Total_investment }}{\text { Annual_cashflow }}$;

In this research, the total life time is assumed 10 years and the effective payback period is found as 5.81 years. The payback period is less than the life time. Thus, the system would be profitable.

5.3 Profitability index: It is defined as the ratio of future cash in-flow and cash out flow. This index determines that, the project would be profitable or not. If the project is profitable, the profitability index would be greater than unity.

$$
\begin{aligned}
& \text { Profitability Index, PI }=\frac{\text { Cash_in }- \text { flow }}{\text { Cash_out }- \text { flow }} ; \text { Or, PI } \\
& =\frac{\text { Annual_cash }- \text { flow } * \text { Project_lifetime }}{\text { Total_investment }} ;
\end{aligned}
$$

In this research, the profitability index is obtained using equation (10) that is greater than unity. It means that the system would be profitable. The Fig.8 shows the profitable period and payback period of the proposed EVCS.

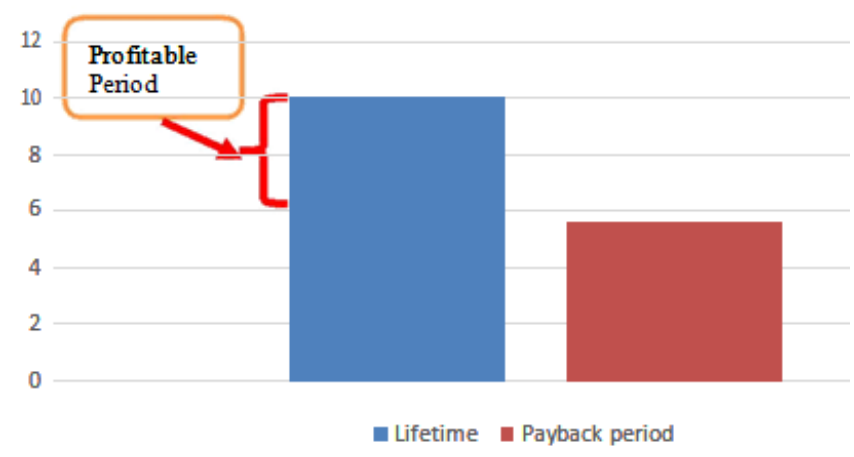

Fig.8: Lifetime and payback period of the proposed EVCS 


\subsection{Environmental aspects of the proposed EVCS}

Electric Vehicles are becoming popular day by day due to their eco-friendly nature. The GHG emission and other pollutants which are noxious to the environment is reduced by using EV. In Bangladesh, the $\mathrm{CO}_{2}$ emission for per unit of electricity generation is approximately equal to $640 \mathrm{~g}$ [63]. The main sources of electricity generation in Bangladesh are natural gas and coal. These two resources are limited and producing large amount of $\mathrm{CO}_{2}$ emission. As compared to these resources, renewable resources like biogas/ biomass has the greater advantages of reducing $\mathrm{CO}_{2}$ penetration from electricity generation purposes. In this proposed charging station, biogas and biomass is used for the purpose of generating electricity which will further charge the EVs. Thus the $\mathrm{CO}_{2}$ emission is reduced significantly by using biogas resources. Fig. 9 shows the comparison of the $\mathrm{CO}_{2}$ emission from the grid based EVCS and biogas based EVCS. In the proposed EVCS, yearly $\mathrm{CO}_{2}$ emission is about $5,840 \mathrm{~kg}$ whereas for the same demand grid based charging station produces $18,688 \mathrm{~kg}$ of $\mathrm{CO}_{2}$. Thus, the $\mathrm{CO}_{2}$ emission is reduced to $68.75 \%$ from the grid based charging station.

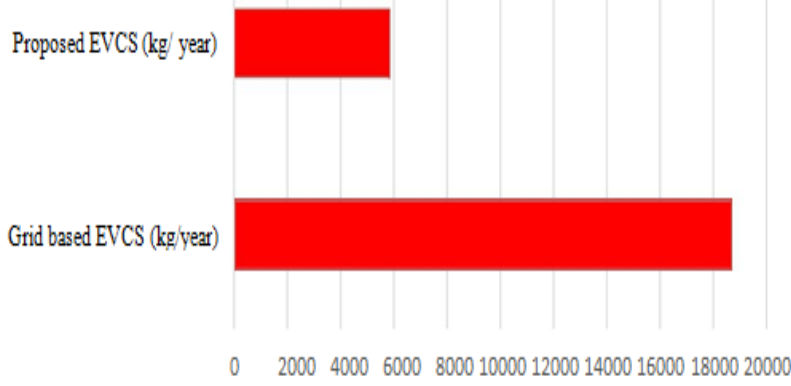

Fig.9: Comparison of $\mathrm{CO}_{2}$ emission from grid based EVCS and proposed EVCS.

The waste material pollutes environment and scatters acrid bad smell to the atmosphere. Utilization of these wastes relief the environment from pollution and bad smell. Another advantage is that, there is a lot of slurry produces which can be used as fertilizer and it makes the atmosphere fresh \& clean. The application of slurry improves the physical, chemical, and biological characters of the soil.

\subsection{Social benefits of the Proposed EVCS}

Electric vehicle charging infrastructure opens a new lucrative area of research and application in Bangladesh. Growing popularity of electric vehicles gives few benefits. Environmental and socio-economic factors are working behind the popularity of electric vehicles. Electric vehicles such as Easy Bikes, Auto- rickshaws and Electric rickshaw vans have high potential of reducing emissions, improving air quality in both urban and rural areas and increasing the income level of the lower class people. An Easy Bike driver in Bangladesh can easily earn approximately \$18-\$25 where the energy consumption cost of this car is only $\$ 1-\$ 1.25$ daily. Due to electric vehicle adaptation the living standard is improved. It cuts the physical labor and saves transportation time. Charging cost of an Easy Bike is around \$53 per month. It will be lower than the present cost if the EVs are charged by the proposed charging station. Table [9] shows the summary of the charging cost in a grid-based system and the proposed EVCS-based system. The monthly savings and monthly income by using this EVCS for an EV driver are given in Table [9].

\begin{tabular}{|c|c|c|c|c|}
\hline $\begin{array}{l}\text { EV } \\
\text { types }\end{array}$ & $\begin{array}{l}\text { Charging } \\
\text { cost/month } \\
\text { (grid) }\end{array}$ & $\begin{array}{l}\text { Charging } \\
\text { cost/month } \\
\text { (proposed } \\
\text { EVCS) }\end{array}$ & $\begin{array}{l}\text { Monthly } \\
\text { savings }\end{array}$ & $\begin{array}{l}\text { Monthly } \\
\text { income }\end{array}$ \\
\hline $\begin{array}{c}\text { Easy } \\
\text { Bike }\end{array}$ & $\$ 53$ & $\$ 25.50$ & $\$ 27.50$ & $\$ 375$ \\
\hline $\begin{array}{c}\text { Auto- } \\
\text { Ricks } \\
\text { haw }\end{array}$ & $\$ 32$ & $\$ 15.75$ & $\$ 16.25$ & $\$ 207$ \\
\hline
\end{tabular}

\subsection{Conclusion}

In Bangladesh, almost all the electric vehicle charging infrastructure are operated by grid electricity. Increased demand of electricity requires more generation. Thus it is necessary to incorporate available renewable energy resources like biogas to increase the generation to charge the electric vehicles. The concept of using biogas/biomass resources for charging battery driven electric vehicles opens a promising area of research and application in Bangladesh. In this paper, the proposed EVCS is found economically feasible and the investment will be returned after 5.80 years. The proposed EVCS saves \$16- \$28 per month than grid based EVCS. In the case of environmental aspect, the proposed EVCS can reduce GHG emissions remarkably. Efficient use of locally available wastes in the proposed EVCS ensures continuous power supply, stability, and reliability of the charging infrastructure. To strengthen the national grid by reducing extra burden like electric vehicle charging by biogas resources can make the energy sector more reliable and, improves power quality towards sustainable development.

Conflicts of Interest: The authors declare no conflicts of interest

\section{References}

[1] Hossain, MA, and Ahmed, MR, Present energy scenario and potentiality of wind energy in Bangladesh. World Academy of Science, Engineering and Technology 7, no. 11 (2013): 1001-1005.

[2] Halder PK, Paul N, Joardder MU, Sarker M. Energy scarcity and potential of renewable energy in Bangladesh. Renewable and Sustainable Energy Reviews. 2015 Nov 30; 51: 1636-49.

[3] Hossain, MA, and Ahmed, MR, Present energy scenario and potentiality of wind energy in Bangladesh, World Academy of Science, Engineering and Technology 7, no. 11 (2013): 1001-1005.

[4] Dominković DF, Bačeković I, Pedersen AS, Krajačić G. The future of transportation in sustainable energy systems: opportunities and barriers in a clean energy transition. Renewable and Sustainable Energy Reviews. 2017 Jul 5.

[5] Durante L, Nielsen M, Ghosh P. Analysis of nonsinusoidal wave generation during electric vehicle charging and their impacts on the power system. International Journal of Process Systems Engineering. 2017; 4(2-3):138-50.

[6] Hossain MF, Hossain S, Uddin MJ. Renewable energy: Prospects and trends in Bangladesh. Renewable and Sustainable Energy Reviews. 2017 Apr 30; 70: 44-9. 
[7] Gholami A, Ansari J, Jamei M, Kazemi A. Environmental/economic dispatch incorporating renewable energy sources and plug-in vehicles. IET Generation, Transmission \& Distribution. 2014 Sep 10; 8(12):218398.

[8] D'Rozario J, Shams S, Rahman S, Sharif A, Basher E. Cost effective solar-biogas hybrid power generation system. In Industrial Technology (ICIT), 2015 IEEE International Conference on 2015 Mar 17 (pp. 2756-2760). IEEE.

[9] Baky MA, Rahman MM, Islam AS. Development of renewable energy sector in Bangladesh: Current status and future potentials. Renewable and Sustainable Energy Reviews. 2017 Jun 30; 73: 1184-97.

[10] Kurtgoz, Yusuf, Emrah Deniz, and Ilker Turker. Solar radiation exergy and enviroeconomic analysis for Turkey. International Journal of Exergy 24, no. 2-4 (2017): 281-300. [11] Anik, D., M. A. M. Bhuiyan, and A. Nasir. "Prospects of solar energy in Bangladesh." IOSR J. Electr. Electron. Eng 4.5 (2013): 46-57.

[12] Islam MT, Shahir SA, Uddin TI, Saifullah AZ. Current energy scenario and future prospect of renewable energy in Bangladesh. Renewable and Sustainable Energy Reviews. 2014 Nov 30; 39: 1074-88.

[13] Shah MS, Halder PK, Shamsuzzaman AS, Hossain MS, Pal SK, Sarker E. Perspectives of Biogas Conversion into Bio-CNG for Automobile Fuel in Bangladesh. Journal of Renewable Energy. 2017; 2017.

[14] Hossen MM, Rahman AS, Kabir AS, Hasan MF, Ahmed S. Systematic assessment of the availability and utilization potential of biomass in Bangladesh. Renewable and Sustainable Energy Reviews. 2017 Jan 31; 67: 94-105.

[15] Das BK, Hoque SM. Assessment of the potential of biomass gasification for electricity generation in Bangladesh. Journal of Renewable Energy, Jun 12; 2014.

[16] Sustainable and Renewable Energy Development Authority, online: www.sreda.gov.bd (accessed on 6 December, 2017)

[17] Waste concern, Bangladesh. Online: www.wasteconcern.org (accessed on 5 December 2017).

[18] Thakur AB, Rikta SY, Easha NJ, Siddik MA, Uddin MK. Physicochemical Composition of the Household Solid Waste and Prospect for Biogas Production. Journal of Environmental Science and Natural Resources. 2017 Apr $14 ; 9(2): 151-4$.

[19] Yousuf A, Khan MR, Pirozzi D, Ab Wahid Z, Atnaw SM. Economic and Market Value of Biogas Technology. In Waste Biomass Management-A Holistic Approach 2017 (pp. 137-158). Springer International Publishing.

[20] Talukder N, Talukder A, Barua D, Das A. Technical and economic assessment of biogas based electricity generation plant. In Electrical Information and Communication Technology (EICT), 2013 International Conference on 2014 Feb 13 (pp. 1-5). IEEE.

[21] Rahman KM, Melville L, Fulford D, Huq SI. Greenhouse gas mitigation capacity of a small scale rural biogas plant calculations for Bangladesh through a general life cycle assessment. Waste Management \& Research. 2017 Oct; 35(10):1023-33.

[22] Rosenberg, Logan Granville. Experimental investigation of biogas production from feedlot cattle manure. Diss. University of Pretoria, 2017.

[23]. Ersoz, Ozben, and Gunnur Kocar, Exergy analysis of solar energy assisted biogas plants for Turkey, International
Journal of Exergy 12, no. 2 (2013): 162-182.

[24] Tasnim F, Iqbal SA, Chowdhury AR. Biogas production from anaerobic co-digestion of cow manure with kitchen waste and Water Hyacinth. Renewable Energy. 2017 Aug 31; 109:434-9.

[25] Optimizingn Anaerobic Digestion.Online: https://www.forestry.gov.uk/pdf/rrps AD250309_optimisin g_anaerobic digestion.pdf/\$file/rrps_AD2503 (accessed on 10 December 2017)

[26] Huda AS, Mekhilef S, Ahsan A. Biomass energy in Bangladesh: Current status and prospects.Renewable and Sustainable Energy Reviews. 2014 Feb 28; 30: 504-17.

[27] Sahoo, Bibhuti B., Ujjwal K. Saha, and Niranjan Sahoo. "Diagnosing the effects of pilot fuel quality on exergy terms in a biogas run dual fuel diesel engine." International Journal of Exergy 10, no. 1 (2012): 77-93.

[28] Matin MF, Istiaque SM. Design and integrate dual renewable energy in a residential building of urban area: A step towards the self-sustained smart energy system for Bangladesh. In Electrical Engineering and Information \& Communication Technology (ICEEICT), 2014 International Conference on 2014 Apr 10 (pp. 1-6). IEEE.

[29] Halder PK, Paul N, Joardder MU, Khan MZ, Sarker M. Feasibility analysis of implementing anaerobic digestion as a potential energy source in Bangladesh. Renewable and Sustainable Energy Reviews. 2016, Nov 30; 65: 124-34.

[30] Peter MK, Alfa MI, Datau G, Aluwong KC, Hadi MI. Design, Development and Performance Evaluation of an Anaerobic Plant. American Journal of Engineering Research. 2017; 6(4):28-33.

[31] Das CK, Kader MA, Alam MJ. Design and Implementation of a Hybrid Energy Neutral Home System for Bangladesh. International Journal of Renewable Energy Resources. 2017 Oct 17; 3(2):66-72.

[32] Hasan AS. The biogas potential from municipal waste and agricultural residues in Hazaribagh, Dhaka city, Bangladesh:-a possible strategy to improve the energy system.

[33] Guha AK, Morshed MN, Dey S, Islam MS, Foisal AB. Sustainable Eco-Friendly Textile Sludge Management In Bangladesh: Construction And Validation Of Lab Scale Biogas Plant For Generation Of Biogas From Textile Sludge. Power. 2015; 37(41.0):40-17.

[34] Khan, Ershad Ullah, Brijesh Mainali, Andrew Martin, and Semida Silveira. "Techno-economic analysis of small scale biogas based polygeneration systems: Bangladesh case study." Sustainable Energy Technologies and Assessments 7 (2014): 68-78.

[35] Kabir H, Yegbemey RN, Bauer S. Factors determinant of biogas adoption in Bangladesh. Renewable and Sustainable Energy Reviews. 2013 Dec 31; 28:881-9

[36] Biogas production technology: An indian perspectives. Online: http://www.iisc.ernet.in/currsci/jul10/articles13.htm (accessed on 04 December 2017).

[37] Gofran MA. Status of biogas technology in Bangladesh. Available Online

http://www.thedailystar.net/story.php?nid=2631; 2007 (accessed on 5 December 2017)

[38] Pathipati VK, Shafiei A, Carli G, Williamson SS. Integration of Renewable Energy Sources into the Transportation and Electricity Sectors. In Technologies and 
Applications for Smart Charging of Electric and Plug-in Hybrid Vehicles 2017 (pp. 65-110). Springer International Publishing.

[39] Verma, Arun Kumar, Bhim Singh, Dilip Tekchand Shahani, and Chinmay Jain. "Grid-interfaced solar photovoltaic smart building with bidirectional power flow between grid and electric vehicle with improved power quality." Electric Power Components and Systems 44, no. 5 (2016): 480-494

[40] Li, Shuhui, Ke Bao, Xingang Fu, and Huiying Zheng. "Energy management and control of electric vehicle charging stations." Electric Power Components and Systems 42, no. 3-4 (2014): 339-347.

[41] Ye, Bin, Jingjing Jiang, Lixin Miao, Peng Yang, Ji Li, and Bo Shen. "Feasibility study of a solar- powered electric vehicle charging station model." Energies 8, no. 11 (2015): 13265-13283.

[42] Ilieva, Liliya Mihaylova, and Simeon Penchev Iliev. "Feasibility assessment of a solar-powered charging station for electric vehicles in the North Central region of Bulgaria." Renewable Energy and Environmental Sustainability 1 (2016): 12.

[43] Ashish kumar karmaker, Md. Raju Ahmed, Md. Alamgir Hossain and Md. Mamun Sikder, "Feasibility assessment \& design of hybrid renewable energy based electric vehicle charging station in Bangladesh" Journal of sustainable cities and society (Elsevier), 2018.

[44] Islam, M. S., Najmul Hoque, and M. R. A. Beg. "ICMEAS 2017 Feasibility Study of Implementing Renewable Energy on an institutional Campus in Bangladesh-A case study." (2017).

[45] Louie, Henry M. "Probabilistic Modeling and Statistical Analysis of Aggregated Electric Vehicle Charging Station Load." Electric Power Components and Systems 43, no. 20 (2015): 2311-2324.

[46] Jensen, Steen Solvang, Morten Winther, Uffe Jørgensen, and Henrik B. Møller. "Scenarios for use of biogas for heavy-duty vehicles in Denmark and related GHG emission impacts." In Proceedings From the

Annual Transport Conference at Aalborg University. 2017.

[47] Leduc, Pierre, Pascal Smague, Arthur Leroux, and Gabriel Henry. "Low temperature heat recovery in engine coolant for stationary and road transport applications." Energy Procedia129 (2017): 834-842.

[48] Singhal, Shailey, Shilpi Agarwal, Shefali Arora, Pankaj Sharma, and Naveen Singhal. "Upgrading techniques for transformation of biogas to bio-CNG: a review." International Journal of EnergyResearch (2017).

[49] Uusitalo, V., R. Soukka, M. Horttanainen, A. Niskanen, and J. Havukainen. "Economics and greenhouse gas balance of biogas use systems in the Finnish transportation sector." Renewable energy 51 (2013): 132140 .

[50] Borba, Bruno Soares MC, Alexandre Szklo, and Roberto Schaeffer. "Plug-in hybrid electric vehicles as a way to maximize the integration of variable renewable energy in power systems: the case of wind generation in northeastern Brazil." Energy 37, no. 1 (2012): 469-481.

51] Lane, Blake, Brendan Shaffer, and G. Scott Samuelsen.

"Plug-in fuel cell electric vehicles: A California case study." International Journal of Hydrogen Energy 42, no. 20 (2017): 14294-14300.

[52] Ammenberg, Jonas, Stefan Anderberg, Tomas
Lönnqvist, Stefan Grönkvist, and Thomas Sandberg. "Biogas in the transport sector-actor and policy analysis focusing on the demand side in the Stockholm region." Resources, Conservation and Recycling 129 (2018): 70-80. [53] Ahuja, Neena, Dipali Bansal, and Khwaja M. Rafi. "Fuzzy computing for feedstock selection in biogas plant." In Soft Computing Techniques and Implementations (ICSCTI), 2015 International Conference on, pp. 72-77. IEEE, 2015.

[54] Turkdogan-Aydınol, F. Ilter, and Kaan Yetilmezsoy. "A fuzzy-logic-based model to predict biogas and methane production rates in a pilot-scale mesophilic UASB reactor treating molasses wastewater." Journal of hazardous materials 182, no. 1 (2010): 460-471.

[55] Source: Biogas - Green energy http://dca.au.dk/fileadmin/DJF/Kontakt/Besog_DJF/Oevelse svejledning_og_baggrundsmateriale/Biogas__Green_Energy_2009_AU.pdf (accessed on 7 December 2017).

[56] Biogas-bikashpedia.

Available Online:

http://vikaspedia.in/energy/energy-production/bioenergy/biogas\#section-2 (accessed on 7 December 2017). [57] Department of livestock services, Bangladesh. Online: www.dls.gov.bd (accessed on 29 November

2017)

[58] Halder, P. K., N. Paul, and M. R. A. Beg. "Assessment of biomass energy resources and related technologies practice in Bangladesh." Renewable and Sustainable Energy Reviews39 (2014): 444-460.

[59] Power cell, Bangladesh. Online: www.powercell.gov.bd . ( accessed on 9 December 2017)

[60] Rennuit, Charlotte, and Sven Gjedde Sommer. "Decision support for the construction of farm-scale biogas digesters in developing countries with cold seasons." Energies 6, no. 10 (2013): 5314-5332.

[61] Pouladi, Jaber, Mohammad Bagher Bannae Sharifian, and Soodabeh Soleymani. "A New Model of Charging Demand Related to Plug-in Hybrid Electric Vehicles Aggregation." Electric Power Components and Systems 45, no. 9 (2017): 964-979.

[62] Jhala, Kumarsinh, Balasubramaniam Natarajan, Anil Pahwa, and Larry Erickson. "Coordinated electric vehicle charging for commercial parking lot with renewable energy sources." Electric Power Components and Systems 45, no. 3 (2017): 344-353.

[63] Das, Barun K., Najmul Hoque, Soumya Mandal, Tapas Kumar Pal, and Md Abu Raihan. "A techno-2 economic feasibility of a stand-alone hybrid power generation for remote area application in 3 Bangladesh."Energy (2017). 